\begin{tabular}{l|l|l} 
Jurnal Eksplorasi Akuntansi & $\begin{array}{l}\text { e-ISSN : 2656-3649 (Online) } \\
\text { http://jea.ppj.unp.ac.id/index.php/jea/index }\end{array}$
\end{tabular}

\title{
Pengaruh Profitabilitas, Ukuran Perusahaan dan Ukuran Kantor Akuntan Publik terhadap Audit Delay Perusahaan Sektor Pertambangan yang Terdaftar di Bursa Efek Indonesia
}

\author{
Halimah Eka Putri ${ }^{1 *}$, Mia Angelina Setiawan ${ }^{2}$ \\ ${ }^{1,2}$ Fakultas Ekonomi, Universitas Negeri Padang \\ *Korespondensi: halimaptri@gmail.com
}

\begin{abstract}
This research aims to examine the effect of profitability, firm size, and KAP size on audit delay. The population in this study are mining companies listed on the Indonesia Stock Exchange (IDX) in 2017-2020. The research sample was determined using the purposive sampling method with a total sample of 29 companies. The data used is secondary data from the company's annual report. The analytical method used is multiple linear regression analysis. The results showed that the profitability had a negative effect on audit delay, the firm size had a positive effect on audit delay, while the KAP size did not affect on audit delay.
\end{abstract}

Keywords : audit delay; profitability; firm size; and KAP size.

How to cite (APA $6^{\text {th }}$ style)

Putri, Halimah Eka \& Setiawan, MA. (2021). Pengaruh Profitabilitas, Ukuran Perusahaan dan Ukuran Kantor Akuntan Publik terhadap Audit Delay Perusahaan Sektor Pertambangan yang Terdaftar di Bursa Efek Indonesia. Jurnal Eksplorasi Akuntansi, 3(3), 529-546.

\section{PENDAHULUAN}

Laporan keuangan yang disediakan oleh masing-masing emiten adalah salah satu sumber informasi penting bagi bisnis investasi di pasar modal. Laporan keuangan yang berkualitas tinggi dapat memberikan informasi bagi pihak internal dan eksternal untuk mengambil keputusan (Putri, 2020). Laporan keuangan suatu emiten yang mengalami keterlambatan dalam penyampaiannya kepada publik akan memberikan pertanda buruk bagi perusahaan, hal tersebut tidak menguntungkan bagi pihak perusahaan yang menyebabkan informasi yang diterima akan kehilangan manfaatnya (Amani \& Waluyo, 2016).

Adapun peraturan terkait yang dikeluarkan oleh Ketua Bapepam dan LK Nomor:Kep431/BL/2012 yang berisi tentang kewajiban penyampaian laporan tahunan emiten atau perusahaan publik. Menurut Bapepam, Laporan tahunan wajib disampaikan kepada Bapepam dan LK paling lama 4 (empat) bulan setelah tahun buku berakhir, jika emiten atau Perusahaan Publik yang pernyataan pendaftarannya telah menjadi efektif. Meskipun telah dibuat peraturan mengenai laporan keuangan, dalam kenyatannya masih banyak perusahaan yang telat menyampaikan laporan keuangan.

Menurut informasi yang dikutip dari Bisnis.com, pada tanggal 9 Juli 2020 setiap tahun masih ditemukannya perusahaan atau emiten yang masih terlambat dalam menyampaikan laporan keuangan auditannya. Adapun pada tahun 2017 tercatat 10 perusahaan, tahun 2018 tercatat 10 perusahaan dan tahun 2019 tercatat 30 perusahaan yang melakukan penundaan 
untuk menyampaikan laporan keuangan. Kesadaran beberapa perusahaan dalam menerbitkan laporan keuangan tepat waktu dinilai masih kurang. Bahkan terjadi kenaikan jumlah perusahaan yang tercatat di Bursa Efek Indonesia (BEI) yang masih terlambat menyampaian laporan keuangan perusahaan, meskipun sudah tersedia peraturan dan sanksi yang cukup jelas pada peraturan tersebut.

Perusahaan yang terlambat menyampaikan laporan keuangan pada tahun 2017 sebagian besar merupakan perusahaan sektor pertambangan dimana terdapat 5 dari 10 perusahaan yang terlambat menyampaikan laporan keuangan yaitu PT Apexindo Jaya International Tbk (APEX), PT Bara Jaya Internasional Tbk (ATPK), PT Borneo Lumbung Energi \& Metal Tbk (BORN), PT Capitalinc Invesment Tbk (MTFN), dan PT Cakra Mineral Tbk (CKRA). Untuk tahun 2018 masih terdapat 3 perusahaan sektor pertambangan yang terlambat menyampaikan laporan keuangan yaitu PT Apexindo Jaya International Tbk (APEX), PT Borneo Lumbung Energi \& Metal Tbk (BORN) dan PT Cakra Mineral Tbk (CKRA). Tahun 2019 juga masih ditemukan 2 perusahaan sektor pertambangan yang terlambat menyampikan laporan keuangan yaitu perusahaan tambang ARTI dan perusahaan tambang GTBO (www.idx.co.id).

Rentang waktu atau jarak yang diperlukan dalam proses audit disebut dengan audit delay. Salah satu kriteria profesionalisme dari seorang auditor yaitu bagaimana penyampaian laporan audit bisa dipublikasikan tepat waktu. Ketepatan waktu perusahaan merilis laporan keuangan kepada publik tergantung pada ketepatan waktu penyelesaian pekerjaan audit yang dilakukan oleh auditor. Bagi emiten, ketepatan waktu dalam menerbitkan laporan keuangan auditan sangat penting. Pentingnya mencegah penundaan audit (audit delay) dalam laporan keuangan mengharuskan auditor untuk menyelesaikan pekerjaan mereka secara tepat waktu. Hal terpenting dalam menyelesaikan audit adalah bagaimana menyampaikan laporan keuangan secara tepat waktu atau tidak tertunda, dan kerahasiaan informasi dalam laporan keuangan tidak akan bocor kepada pihak lain yang tidak dapat mempengaruhi laporan keuangan (Eksandy, 2017).

Ada beberapa faktor yang mempengaruhi audit delay baik dari faktor internal dan eksternal perusahaan. Faktor-faktor yang mempengaruhi audit delay dari internal perusahaan adalah ukuran perusahaan, profitabilitas dan solvabilitas (Karang et al, 2015). Reputasi auditor, kualitas auditor, dan opini audit adalah faktor yang berasal dari eksternal perusahaan itu sendiri yang dapat mempengaruhi audit delay (Ashton et al, 1987). Dalam penelitian ini peneliti menggunakan faktor eksternal dan faktor internal perusahaan yaitu profitabilitas, ukuran perusahaan dan ukuran kantor akuntan publik.

Profitabilitas merupakan suatu cara untuk mengukur atau mendeskripsikan efektivitas kinerja manajemen berdasarkan laba yang diperoleh perusahaan, oleh karena itu semakin tinggi profitabilitas maka semakin tinggi pula kemampuan perusahaan dalam menghasilkan laba. Hasil penelitian Prabasari \& Merkusiwati (2017) mengungkapkan bahwa profitabilitas tidak berpengaruh pada audit delay. Sejalan dengan penelitian Lestari \& Nuryatno (2018) menunjukkan bahwa profitabilitas tidak berpengaruh signifikan terhadap keterlambatan audit pada perusahaan yang tercatat di Bursa Efek Indonesia. Hal ini berbeda dengan penelitian yang dilakukan oleh Rusmin \& Evans (2017) tentang Audit quality and audit report lag: case of Indonesian listed companies. Hasil penelitian ini melaporkan adanya pengaruh yang signifikan dan statistik antara profitabilitas perusahaan dan ketertinggalan laporan audit. Sejalan dengan penelitian yang dilakukan Liwe, dkk (2018) Profitabilitas berpengaruh signifikan terhadap audit delay.

Ukuran perusahaan merupakan gambaran besar ataupun kecilnya perusahaan yang dapat dilihat dari besarnya nilai ekuitas, nilai penjualan atau nilai aktiva. Hasil penelitian (Eksandy, 2017) menunjukkan bahwa ukuran perusahaan tidak berpengaruh terhadap audit delay. Hal ini karena baik perusahaan yang memiliki ukuran besar ataupun perusahaaan 
ukuran kecil akan secara profesional dan maksimal supaya dapat mengurangi terjadinya audit delay. Sejalan dengan hasil penelitian Sari \& Mulyani (2019) menemukan bahwa ukuran perusahaan tidak berpengaruh signifikan terhadap keterlambatan audit. Namun Hasil penelitian Lestari \& Nuryatno (2018) dan Kaaroud, dkk (2020) menunjukkan bahwa ukuran perusahaan berpengaruh signifikan terhadap penundaan audit perusahaan di Bursa Efek Indonesia.

Ukuran kantor akuntan publik (KAP) merupakan skala besar kecilnya KAP yang digunakan oleh suatu perusahaan. Skala besar dalam penelitian ini adalah KAP yang tergolong "Big Four". Kantor Akuntan Publik (KAP) yang bekerjasama dengan KAP Big Four, memiliki jumlah auditor dan karyawan yang handal dalam jumlah besar, sehingga dapat bekerja secara efektif dan mempercepat proses audit (Clarisa \& Pangerapan, 2019). Penelitian yang dilakukan oleh Hassan (2016) tentang determinants of audit report lag: evidence from Palestina. Hasil penelitian ini menemukan bahwa keterlambatan pelaporan audit dipengaruhi oleh status perusahaan audit yang diaudit oleh kantor akuntan publik Big Four. Berbeda dengan hasil penelitian Lestari \& Nuryatno (2018) menyatakan bahwa audit reputasi tidak berpengaruh terhadap audit delay.

Penelitian ini mengacu pada penelitian Effendi (2018) yang menguji pengaruh ukuran perusahaan dan ukuran KAP terhadap audit delay. Penelitian tersebut menemukan hasil bahwa ukuran perusahaan tidak memiliki pengaruh terhadap audit delay, artinya semakin besar ukuran perusahaan tidak mempengaruhi audit delay. Lalu untuk variabel ukuran KAP juga tidak memiliki pengaruh terhadap audit delay, dikarenakan seorang auditor yang berasal dari KAP Big Four ataupun non Big Four akan selalu tetap melaksanakan Standar Auditing (SA No.01 Seksi 150) yang ditetapkan oleh Ikatan Akuntan Indenesia (IAI) yang terdiri dari Standar Umum, Standar Pekerjaan Lapangan dan Standar Pelaporan (IAI, 2011).

Perbedaan penelitian ini dengan penelitian Effendi (2018) yaitu pertama, pada penelitian ini peneliti menambahkan satu variabel independen yaitu profitabilitas. Profitabilitas adalah salah satu indikator keberhasilan suatu perusahaan dalam menghasilkan laba, oleh karena itu semakin tinggi profitabilitas maka semakin tinggi pula kemampuan perusahaan dalam menghasilkan laba bagi perusahaan. Jika profitabilitas perusahaan rendah, auditor akan lebih berhati-hati dalam melakukan tugas audit karena terdapat risiko bisnis yang lebih tinggi, yang akan memperlambat proses audit dan mengakibatkan laporan audit menjadi lebih panjang (Eksandy, 2017).

Perbedaan kedua, pengukuran variabel profitabilitas pada penelitian ini menggunakan Return On Equity (ROE) yang mengacu pada penelitian (Eksandy, 2017). Ketiga objek penelitian ini menggunakan perusahaan sektor pertambangan yang terdaftar di Bursa Efek Indonesia tahun 2017-2020. Sektor pertambangan adalah salah satu sektor utama pendorong kebangkitan IHSG (Comprehensive Stock Price Index) atau Index Harga Saham Gabungan, dimana saham sektor pertambangan memiliki likuiditas yang tinggi dan menjadi pilihan utama investor. Oleh karena itu, informasi keuangan perusahaan pertambangan harus dikeluarkan secara tepat waktu dan akurat, karena hal ini sangat penting untuk permintaan investor atas informasi tersebut. Namun hal tersebut belum tercapai dengan baik, karena sebagaimana disebutkan di atas, masih banyak perusahaan pertambangan yang mengalami keterlambatan penyampaian laporan keuangan yang telah diaudit (Shaena, dkk 2020).

\section{REVIEW LITERATUR DAN PENGEMBANGAN HIPOTESIS}

\section{Teori Agensi (Agency Theory)}

Teori keagenan (agency theory) muncul ketika hubungan satu orang atau lebih pemilik saham (principal) yang memperkerjakan orang lain atau seorang manajer (agent) untuk memberikan suatu jasa dan kemudian mendelegasikan wewenang pengambilan keputusan kepada manajer (agent) tersebut. Dalam hal ini agency theory menjelaskan adanya biaya 
keagenan yang dikeluarkan oleh pemilik saham (principal) agar bisa memonitoring setiap tindakan manajer (agent) sehingga keterlambatan waktu penyampaian laporan keuangan auditan akan dapat diatasi (Jensen \& Meckling, 1976).

Pada penelitian ini, profitabilitas dan ukuran perusahaan merupakan besaran dan karakteristik yang dipercayakan oleh pemilik saham (principal) pada manajer (agent), sedangkan ukuran kantor akuntan publik (KAP) merupakan mediator penengah agar dapat mengurangi asimetri informasi antara pemilik saham dan manajer.

\section{Teori Kepatuhan}

Teori kepatuhan pertama kali diciptakan oleh Stanley Milgram (1963) dalam Shaena et al., (2020), kepatuhan merupakan tindakan yang dilakukan oleh seseorang, kelompok ataupun organisasi tertentu untuk melakukan atau tidak melakukan suatu tindakan yang sesuai dengan aturan yang berlaku. Teori ini mampu membantu seseorang untuk lebih mematuhi aturanaturan yang berlaku. Hal ini mirip seperti perusahaan yang berusaha ingin menyampaikan laporan keuangan tepat waktu karena laporan keuangan yang disampaikan tepat waktu mengandung informasi yang lebih bermanfaat bagi pengguna laporan keuangan, selain itu penyampaian laporan keuangan yang tepat waktu merupakan suatu kewajiban bagi perusahaan (Annisa, 2018).

\section{Laporan Keuangan}

Menurut PSAK No.1(2015:2) laporan keuangan adalah salah satu bagian dari proses pelaporan keuangan. Laporan keuangan merupakan suatu dokumen informasi yang berisi tentang keadaan keuangan suatu perusahaan yang informasinya berguna bagi pemakai laporan keuangan. Kelengkapan laporan keuangan biasanya terdiri atas laporan posisi keuangan, laporan laba rugi, laporan perubahan modal (ekuitas), laporan arus kas, dan catatan atas laporan keuangan, serta materi penjelasan lainnya yang merupakan bagian pelengkap laporan keuangan suatu emiten.

\section{Audit Delay}

Audit delay juga sering disebut dengan audit report lag yaitu rentang waktu atau lamanya waktu penyelesaian audit yang biasanya diukur dari tanggal penutupan tahun buku hingga dengan tanggal diterbitkannya laporan audit suatu emiten (Harjanto, 2017). Lamanya auditor mengaudit laporan keuangan suatu perusahaan juga berhubungan dengan audit delay, yang dihitung dari tanggal penugasan audit sampai tanggal berakhirnya pekerjaan audit. Lamanya waktu dalam proses pengauditan ini biasanya dipengaruhi oleh internal control perusahaan. Audit delay menyarankan agar laporan keuangan disajikan pada suatu selang waktu tertentu, supaya dapat menjelaskan perubahan didalam perusahaan yang mungkin dapat mempengaruhi pengguna laporan keuangan pada waktu mengambil keputusan. Informasi pada laporan keuangan akan kehilangan nilainya apabila informasi tersebut tidak disampaikan tepat waktu sehingga mempengaruhi kualitas keputusan (Eksandy, 2017).

\section{Profitabilitas}

Profitabilitas merupakan suatu cara untuk mengukur atau mendeskripsikan efektifitas kinerja manajeman berdasarkan laba yang diperoleh perusahaan, oleh karena itu semakin tinggi profitabilitas maka semakin tinggi pula kemampuan perusahaan dalam menghasilkan laba. Profitabilitas dapat dilihat dari income statement yang mencerminkan kinerja suatu perusahaan dalam satu periode. Profitabilitas umumnya sebagai indikator yang digunakan untuk mengukur keberhasilan manager dalam mencapai tujuan yang telah ditetapkan (Devina \& Fidiana, 2019). 
Profitabilitas keuangan perusahaan dicerminkan dalam bentuk laporan laba-rugi yang merupakan salah satu bagian dari laporan keuangan, yang dapat digunakan untuk membuat keputusan ekonomi oleh semua pihak yang berkepentingan. Suatu perusahaan yang memiliki rasio profitabilitas yang besar, maka perusahaan akan semakin baik dalam menghasilkan keuntungan (Shaena et al., 2020).

\section{Ukuran Perusahaan}

Menurut Ferri \& Jones (1979) ukuran perusahaan merupakan skala yang dapat dikelompok besar atau kecilnya suatu perusahaan dengan berbagai cara, diantaranya: total aset, penjualan, ukuran log, nilai pasar saham, nilai pasar, dan lain lain yang semuanya berkorelasi tinggi. Semakin besar total aset, penjualan, ukuran log, nilai pasar saham dan nilai pasar, semakin besar skala perusahaan. Dalam Undang-Undang No.20 Tahun 2008 ukuran perusahaan dapat diklasifikasikan menjadi 4 yaitu usaha mikro, usaha kecil, usaha menengah dan usaha besar.

\section{Ukuran Kantor Akuntan Publik}

Dalam Undang-Undang RI No. 5 tahun 2011 yang disebut dengan kantor akuntan publik (KAP) adalah badan usaha yang didirikan sesuai dengan ketentuan peraturan perundangundangan dan memperoleh izin usaha sesuai dengan ketentuan peraturan perundang-undangan. Menurut data Pusat Pengembangan Profesi Keuangan (PPPK), skala kantor akuntan publik pada tahun 2015 terbagi menjadi 5 (lima), yaitu KAP kecil, KAP sedang, KAP besar, KAP super besar dan KAP Big Four. Ukuran kantor akuntan publik merupakan suatu ukuran untuk melihat besar atau kecilnya kantor akuntan publik. Ukuran KAP yang dikatakan besar yaitu KAP yang termasuk Big Four dan KAP yang dikatakan kecil adalah KAP yang tidak termasuk Big Four.

\section{Hubungan Profitabilitas dan Audit Delay}

Jika perusahaan memperoleh laba yang tinggi, maka perusahaan tersebut dikatakan berhasil. Perusahaan dengan tingkat profitabilitas yang lebih tinggi akan lebih cepat menyampaikan laporan keuangan auditan (Jayanti, 2018). Perusahaan yang menghasilkan laba cenderung melaporkan laporan keuangannya lebih cepat karena ada kabar baik untuk disampaikan kepada investor melalui laporan keuangan. Oleh karena itu, perusahaan akan menyediakan semua kebutuhan auditor untuk segera menyelesaikan proses audit, sehingga semakin besar profitabilitas maka risiko perusahaan mengalami audit delay semakin rendah (Clarisa \& Pangerapan, 2019).

Menurut Putra \& Wiratmaja (2019) dalam penelitiannya menjelaskan bahwa profitabilitas memiliki pengaruh negatif terhadap audit delay yang artinya semakin tinggi profitabilitas suatu emiten, maka semakin pendek audit delay. Perusahaan yang memiliki profit atau laba yang besar maka perusahaan tersebut cenderung menyampaikan laporan keuanganya tepat waktu sehingga proses audit menjadi lebih singkat dan menekan terjadinya audit delay

H1: Profitabilitas berpengaruh negatif terhadap audit delay

\section{Hubungan Ukuran Perusahaan dan Audit Delay}

Ukuran perusahaan merupakan suatu ukuran yang menyatakan besar kecilnya suatu perusahaan yang ditandai dengan beberapa ukuran antara lain total penjualan, total aktiva, $\log$ size, total pegawai, nilai pasar perusahaan, dan nilai buku perusahaan (Ariani \& Bawono, 2018). Dibandingkan dengan perusahaan kecil, karakteristik perusahaan besar cenderung memiliki kompleksitas operasional yang lebih tinggi, dan diperlukan waktu yang relatif lama dalam proses persiapan dan proses audit, yang menyebabkan audit delay (Oktavia \& Suryaningrum, 2018). 
Penelitian Clarisa \& Pangerapan (2019) menyatakan bahwa ukuran perusahaan memiliki pengaruh positif terhadap audit delay. Hal ini disebabkan oleh semakin besarnya ukuran perusahaan yang mengakibatkan prosedur audit yang harus dilakukan juga semakin banyak karena perusahaan yang berukuran besar mempunyai kegiatan yang lebih luas, volume kegiatan bertambah, kuantitas transaksi dalam perusahaan semakin tinggi sehingga kerumitan transaksi meningkat. Audit delay akan lebih lama jika ukuran perusahaan yang diaudit semakin besar. Jadi, dapat dikatakan bahwa semakin besar ukuran perusahaan karena aktivitas operasional yang luas maka semakin besar peluang terjadinya audit delay.

H2: Ukuran Perusahaan berpengaruh positif terhadap audit delay.

\section{Hubungan Ukuran Kantor Akuntan Publik dan Audit Delay}

Dibandingkan dengan perusahaan yang diaudit oleh KAP kecil (non Big 4), perusahaan yang diaudit oleh KAP besar (termasuk Big 4) memiliki audit delay yang lebih singkat, dan perusahaan yang diaudit oleh KAP kecil membutuhkan waktu lebih lama untuk menyelesaikan audit tepat waktu. Hal ini karena KAP yang lebih besar memiliki pengetahuan dan pemahaman yang lebih tentang perusahaan yang diaudit, dan KAP yang lebih besar biasanya memiliki reputasi yang baik. KAP dengan reputasi yang baik diperlukan untuk menghasilkan laporan keuangan auditan yang berkualitas tinggi dalam waktu yang singkat (Widiastuti \& Kartika, 2018). Perusahaan yang diaudit KAP besar akan memiliki audit delay yang lebih singkat dibandingkan dengan perusahaan yang diaudit KAP kecil (Yunita \& Syofyan, 2017).

KAP big four dapat melakukan proses audit lebih efisien dan efektif, serta memiliki fleksibilitas yang lebih tinggi dalam penjadwalan audit. Hal ini menimbulkan asumsi bahwa perusahaan yang diaudit oleh KAP Big Four cenderung menyelesaikan tugas auditnya lebih cepat dibandingkan dengan KAP non Big Four (Shaena et al., 2020). Dapat disimpulkan ukuran KAP berpengaruh negatif terhadap audit delay karena perusahaan yang diaudit oleh KAP besar (termasuk KAP Big Four) memiliki kualitas yang lebih baik dan sumber daya yang memadai sehingga menyebabkan audit delay lebih singkat.

H3: Ukuran KAP berpengaruh negatif terhadap audit delay

\section{METODE PENELITIAN}

\section{Jenis Penelitian}

Jenis data yang digunakan dalam penelitian ini yaitu data kuantitatif sebab, penggunaan data yang berbentuk angka atau dijadikan angka dalam melakukan analisis. Menurut Sugiyono (2016:8) bentuk metode penelitian kuantitatif digambarkan sebagai metode penelitian yang berlandaskan pada aliran positivisme (sesuai fakta yang ada), yang digunakan oleh peneliti untuk meneliti pada populasi ataupun sampel tertentu.

\section{Populasi dan Sampel}

Dalam penelitian ini populasi yang digunakan adalah seluruh perusahaan sektor pertambangan yang terdaftar di Bursa Efek Indonesia (BEI) periode tahun 2017-2020 dengan jumlah populasi pada penelitian ini adalah sebanyak 45 perusahaan. Untuk pengambilan sampel menggunakan teknik purposive sampling, merupakan suatu teknik pengambilan sampel penelitian dengan kriteria dan pertimbangan tertentu yang sesuai dengan tujuan penelitian. Sampel dalam penelitian ini yaitu sebanyak 29 perusahaan yang memenuhi kriteria pada perusahaan pertambangan yang terdaftar di Bursa Efek Indonesia tahun 2017-2020.

\section{Metode Pengumpulan Data}

Sumber data yang digunakan dalam penelitian ini adalah data sekunder. Metode pengumpulan data dalam penelitian ini menggunakan metode dokumentasi, merupakan metode 
pengumpulan data yang dilakukan dengan cara mempelajari, mengelompokkan, dan menganalisis data sekunder berupa laporan keuangan, laporan keuangan auditan, dan laporan auditor independen, maupun informasi lainnya yang diperoleh berupa laporan keuangan auditan perusahaan yang terdaftar di Bursa Efek Indonesia periode 2017-2020 yang sudah dipublikasikan. Data penelitian diperoleh dari website resmi BEI yaitu www.idx.co.id dan website resmi masing-masing perusahan.

\section{Variabel Penelitian dan Pengukuran Variabel Dependen}

Variabel dependen atau variabel terikat dalam penelitian ini adalah audit delay. Audit delay merupakan senjang waktu audit, artinya waktu yang diperlukan oleh auditor dalam menghasilkan laporan audit atas kinerja laporan keuangan suatu emiten (Murti \& Widhiyani, 2016). Audit delay diukur dengan melihat seberapa jarak antara penutupan tahun buku sampai ditandatanganinya laporan keuangan auditan.

Audit Delay: Tanggal Laporan Keuangan - Tanggal Laporan Auditor

\section{Variabel Independen \\ Profitabilitas}

Menurut Kasmir (2016:196), rasio profitabilitas adalah rasio yang memperhitungkan kemampuan perusahaan dalam mencari keuntungan ataupun laba dalam periode tertentu. Dalam penelitian ini variabel profitabilitas diukur dengan Return On Equity (ROE).

Return On Equity (ROE) $\frac{\text { Laba Bersih Setelah Pajak }}{\text { Total Ekuitas }} \times 100 \%$

\section{Ukuran Perusahaan}

Ukuran perusahaan merupakan ukuran yang menunjukkan besar kecilnya perusahaan yang bisa dilihat dari berbagai cara diantaranya yaitu dari jumlah penjualan, total aset, log size, total pegawai, nilai pasar perusahaan, dan nilai buku perusahaan dan lain-lain. Dalam penelitian ini, ukuran perusahaan diproksikan dengan menggunakan Logaritma natural ( $L n$ ) total asset.

Ukuran Perusahaan $=$ Ln Total Aset

\section{Ukuran Kantor Akuntan Publik}

Ukuran KAP adalah suatu ukuran untuk melihat besar atau kecilnya Kantor Akuntan Publik (KAP). Ukuran KAP yang dikatakan besar yaitu KAP yang termasuk big four dan KAP yang dikatakan kecil adalah KAP yang tidak termasuk Big Four, dalam penelitian ini ukuran KAP dapat diukur dengan variabel dummy, yaitu perusahaan yang menggunakan jasa KAP yang termasuk big four diberi kode 1 (satu) dan perusahaan yang tidak memakai jasa KAP Big Four diberi kode 0 (nol).

\section{Metode Analisi Data}

Metode analisis data yang digunakan oleh penelitian dalam penelitian ini yaitu metode analisis statistik. Sedangkan alat analisis yang digunakan adalah analisis regresi linear berganda dengan menggunakan bantuan SPSS (Statistic Package for Social Science) untuk mengolah data dalam penelitian. 


\section{HASIL DAN PEMBAHASAN \\ Analisis Statistik Deskriptif}

Statistik deskriptif adalah metode yang digunakan untuk menganalisa data yang dimiliki dengan cara mendeskripsikan data yang sudah dikumpulkan (Sugiyono, 2016:147). Adapun hasil analisis statistik deskriptif pada perusahaan sektor pertambangan yang terdaftar di Bursa Efek Indonesia tahun 2017-2020 dengan menggunakan SPSS versi 24 pada masing-masing variabel penelitian dapat dilihat pada tabel 1 berikut.

Tabel 1

Statistik Deskriptif

\begin{tabular}{llllll}
\hline & $\mathrm{N}$ & Minimum & Maximum & Mean & Std. Deviation \\
\hline Profitabilitas & 116 & -2.90 & .85 & .0603 & .42573 \\
Ukuran Perusahaan & 116 & 24.12 & 32.26 & 29.3517 & 1.88146 \\
Audit Delay & 116 & 31 & 151 & 84.81 & 24.072 \\
Valid N (listwise) & 116 & & & & \\
\hline
\end{tabular}

Sumber: Data diolah SPSS, 2021

Pada tabel 1 dengan sampel 116 data penelitian pada perusahaan sektor pertambangan yang terdaftar di Bursa Efek Indonesia tahun 2017-2020, dapat dilihat bahwa variabel profitabilitas yang diproksikan dengan return on equity (ROE) diperoleh nilai minimum sebesar -2,90 dan nilai maximum sebesar 0,85 dengan nilai rata-rata sebesar 0,0603 dan standar deviasi sebesar 0,42573. Ukuran perusahaan yang diukur menggunakan logaritma natural (LN total aset) memiliki nilai berkisar antara 24,12 dan 32,26 dengan nilai rata-rata sebesar 29,3517. Standar deviasi ukuran perusahaan sebesar 1,88146 yang artinya terjadi penyimpangan sebesar 1,88146. Nilai rata-rata pada audit delay yang diukur dengan melihat lamanya waktu yang dibutuhkan auditor untuk menghasilkan laporan audit pada perusahaan sektor pertambangan yang terdaftar di Bursa Efek Indonesia tahun 2017-2020 yaitu sebesar 84,81. Nilai standar deviasi sebesar 24,072.

\begin{tabular}{llcccc}
\multicolumn{5}{c}{$\begin{array}{c}\text { Tabel } 2 \\
\text { Statistik Deskriptif } \\
\text { Variabel Ukuran Kantor } \\
\text { Ukuran KAP }\end{array}$} & Akuntan Publik \\
\hline & Frequency & Percent & $\begin{array}{c}\text { Valid } \\
\text { Percent }\end{array}$ & $\begin{array}{c}\text { Cumulative } \\
\text { Percent }\end{array}$ \\
\hline Valid & KAP Non Big Four & 58 & 50.0 & 50.0 & 50.0 \\
& KAP Big Four & 58 & 50.0 & 50.0 & 100.0 \\
& Total & 116 & 100.0 & 100.0 & \\
\hline
\end{tabular}

Sumber : Data diolah SPSS, 2021

Dari tabel 2 di atas dapat dilihat bahwa dari 116 data perusahaan sektor pertambangan periode tahun 2017-2020 terdapat perusahaan yang tidak diaudit oleh KAP Big Four sebanyak 58 data perusahaan dengan persentase $50 \%$ sementara perusahaan yang diaudit oleh KAP Big Four sebanyak 58 data perusahaan dengan persentase sebesar 50\%. Artinya perusahaan pertambangan yang terdaftar di Bursa Efek Indonesia tahun 2017-2020 menggunakan jasa Kantor Akuntan Publik big four dan Kantor Akuntan Publik non big four sama banyak dengan persentase $50 \%$.

\section{Uji Asumsi Klasik}

\section{Uji Normalitas}

Uji normalitas bertujuan untuk menguji apakah suatu model regresi pada variabel dependent dan variabel independent terdistribusi secara normal atau terdistribusi secara tidak normal, 
model regresi yang baik adalah yang terdistribusi secara normal atau bisa dikatakan memiliki nilai signifikan $>0,05$.

Tabel 3

Uji Normalitas

Test Statistic

Asymp. Sig. (2-tailed)

Monte Carlo Sig. (2-tailed)

a. Test distribution is Normal.

b. Calculated from data.

c. Lilliefors Significance Correction.

d. Based on 10000 sampled tables with starting seed 1314643744 .
.116

$.001^{\mathrm{c}}$

Sig.

$.080^{\mathrm{d}}$

99\% Confidence Interval

Lower Bound

.073

Upper Bound

Sumber : Data diolah SPSS, 2021

Dari tabel 3 di atas dapat dilihat bahwa dari jumlah sampel 116 data pada perusahaan sektor pertambangan yang terdaftar di BEI tahun 2017-2020 dengan menggunakan pengujian Monte Carlo Sig (2-tailed), maka diperoleh nilai uji normalitas sebesar 0,08 > 0,05 yang artinya data dalam penelitian ini berdistribusi dengan normal sehingga model dapat dilanjutkan dalam penelitian.

\section{Uji Multikolinearitas}

Uji Multikolinearitas bertujuan untuk menguji korelasi antara satu variabel independen dengan variabel independen lainnya. Suatu model regresi yang baik adalah yang bebas dari multikolinearitas. Model regresi yang bebas dari uji multikolinearitas yaitu yang mempunyai nilai VIF $<10$ dan nilai tolerance $>0,10$.

Tabel 4

Uji Multikolinearitas

\begin{tabular}{llll}
\hline \multicolumn{1}{c}{ Model } & & Collinearity Statistics \\
& Profitabilitas & .939 & VIF \\
\hline $1 \quad$ Ukuran Perusahaan & .726 & 1.065 \\
& Ukuran KAP & .689 & 1.377 \\
\multicolumn{2}{l}{ a. Dependent Variable: Audit Delay } & & 1.452 \\
\hline
\end{tabular}

Sumber : Data diolah SPSS, 2021

Pada tabel 4 di atas dapat dilihat bahwa nilai tolerance untuk variabel profitabilitas sebesar 0,939, nilai tolerance untuk variabel ukuran perusahaan sebesar 0,726 dan nilai tolerance untuk variabel ukuran KAP sebesar 0,689. Ketiga variabel independent diatas diperoleh nilai tolerance $>0,10$. Sementara, nilai VIF untuk variabel profitabilitas sebesar 1,065 nilai VIF untuk variabel Ukuran Perusahaan sebesar 1,377 dan nilai VIF untuk variabel Ukuran KAP sebesar 1,452. Melihat hasil VIF untuk semua variabel penelitian $<10$, maka data-data penelitian digolongkan tidak terdapat gejala multikolinearitas dalam model regresinya. 


\section{Uji Autokorelasi}

Uji autukorelasi bertujuan untuk mengetahui ada atau tidaknya korelasi pada variabel. Dalam penelitian ini uji autokorelasi menggunakan uji Run Test. Jika Asymp.sig (2-tailed) > 0,05 maka tidak terjadi gejala autokorelasi dalam model penelitian. Model regresi yang bebas dari autokorelasi adalah model regresi yang baik.

Tabel 5

Uji Autokorelasi Run Test

Runs Test

Asymp. Sig. (2-tailed)

0.223

a. Median

Sumber : Data diolah SPSS, 2021

Pada tabel 5 di atas dapat dilihat bahwa dari hasil perhitungan diperoleh nilai Asmp. Sig (2-tailed) sebesar 0,223 lebih besar dari $0,05(0,223>0,05)$ artinya tidak terjadi autokorelasi dalam model penelitian ini.

\section{Uji Heteroskedastisitas}

Uji heteroskedastisitas bertujuan untuk melihat apakah dalam suatu model regresi terdapat ketidaksamaan varian dari residual satu pengamatan ke pengamatan yang lain. Untuk melihat uji heteroskedastisitas peneliti menggunakan uji Glejser dengan melihat nilai signifikansi. Jika nilai signifikansi besar dari $0,05(>0,05)$ maka tidak terjadi gejala heteroskedastisitas

\section{Tabel 6}

\section{Uji Heteroskedastisitas Glejser}

\begin{tabular}{|c|c|c|c|c|c|c|}
\hline & \multirow[t]{2}{*}{ Model } & \multicolumn{2}{|c|}{$\begin{array}{l}\text { Unstandardized } \\
\text { Coefficients }\end{array}$} & \multirow{2}{*}{$\begin{array}{c}\text { Standardized } \\
\text { Coefficients } \\
\text { Beta }\end{array}$} & \multirow[t]{2}{*}{$\mathrm{T}$} & \multirow[t]{2}{*}{ Sig. } \\
\hline & & B & Std. Error & & & \\
\hline \multirow[t]{4}{*}{1} & (Constant) & 7.892 & 8.270 & & .954 & .342 \\
\hline & Profitabilitas & 1.051 & 3.036 & .033 & .346 & .730 \\
\hline & Ukuran Perusahaan & .383 & .344 & .122 & 1.112 & 268 \\
\hline & Ukuran KAP & -1.043 & 3.012 & -.039 & -.346 & .730 \\
\hline
\end{tabular}

\section{Sumber : Data diolah SPSS, 2021}

Dari Tabel 6 diatas dapat dilihat bahwa nilai signifikansi dari masing-masing variabel profitabilitas yaitu sebesar 0,730 nilai untuk variabel ukuran perusahaan yaitu sebesar 0,268 dan nilai untuk variabel ukuran KAP yaitu 0,730 lebih besar dari 0,05 yang artinya tidak terjadi heteroskedastisitas dalam penelitian ini. Model regresi yang baik adalah yang bebas dari heteroskedasitas.

\section{Analisis Regresi Linier Berganda}

Analisis regresi linier berganda adalah suatu analisis yang digunakan untuk melihat pengaruh dua atau lebih variabel independen (X) terhadap satu variabel dependen (Y). 
Tabel 7

Regresi Linier Berganda

\begin{tabular}{|c|c|c|c|c|}
\hline & \multirow{2}{*}{ Model } & \multicolumn{2}{|c|}{ Unstandardized Coefficients } & \multirow{2}{*}{$\begin{array}{c}\text { Standardized } \\
\text { Coefficients } \\
\text { Beta }\end{array}$} \\
\hline & & B & Std. Error & \\
\hline \multirow{4}{*}{1} & (Constant) & 46.571 & 12.898 & \\
\hline & Profitabilitas & -19.934 & 4.735 & -0.353 \\
\hline & Ukuran Perusahaan & 1.872 & 0.537 & 0.332 \\
\hline & Ukuran KAP & -1.464 & 4.698 & -0.03 \\
\hline
\end{tabular}

Sumber : Data diolah SPSS, 2021

Berdasarkan olah data yang dilakukan maka diperoleh persamaan regresi linier berganda pada pada perusahaan pertambangan yang terdaftar di Bursa Efek Indonesia tahun 2017 sampai tahun 2020 adalah sebagai berikut:

$Y=46,571-19,934 X 1+1,872 X 2-1,464 X 3$

Dari persamaan regresi diatas, maka dapat dijelaskan bahwa konstanta sebesar 46,571 menunjukkan bahwa apabila variabel Profitabilitas (X1), Ukuran Perusahaan (X2) dan Ukuran KAP (X3) bernilai 0 maka nilai audit delay (Y) sebesar 46,571 hari. Koefisien regresi untuk profitabilitas $(\beta 1)$ sebesar -19,934 artinya, jika variabel lainnya tetap dan profitabilitas mengalami kenaikan 1\% maka audit delay akan mengalami penurunan sebesar 19,934. Koefisien regresi bernilai negatif artinya terjadi hubungan berlawanan arah antara profitabilitas dan audit delay, semakin besar profit yang dimiliki suatu perusahaan maka audit delay relatif lebih singkat. Koefisien regresi untuk ukuran perusahaan $(\beta 2)$ sebesar 1,872 artinya jika variabel lainnya tetap dan ukuran perusahaan mengalami kenaikan 1 (Log Natural) maka audit delay akan mengalami pertambahan sebesar 1,872. Koefisien regresi bernilai positif artinya terjadi hubungan searah antara ukuran perusahaan dan audit delay, semakin besar ukuran perusahaan maka, semakin memungkinkan perusahaan mengalami audit delay.

Koefisien regresi untuk ukuran KAP $(\beta 3)$ sebesar -1,464 artinya jika variabel lainnya tetap dan ukuran KAP mengalami kenaikan 1\% maka audit delay akan mengalami penurunan sebesar 1,464. Koefisien regresi bernilai negatif artinya terjadi hubungan berlawanan arah antara ukuran KAP dan audit delay. KAP skala besar dalam penelitian ini adalah KAP Big Four, memiliki kualitas auditor yang handal serta dapat bekerja secara efektif dan efisien sehingga mempercepat proses audit yang menyebabkan audit delay relatif lebih singkat. Semakin besar ukuran KAP maka jangka waktu audit delay relatif lebih singkat.

\section{Uji Hipotesis}

\section{Uji Parsial (Uji t)}

Uji t digunakan untuk mengetahui pengaruh masing-masing variabel independen yaitu profitabilitas, ukuran perusahaan dan ukuran KAP terhadap audit delay. 
Tabel 8

Uji Parsial

\begin{tabular}{lllllll}
\hline \multirow{2}{*}{ Model } & \multicolumn{2}{c}{ Unstandardized Coefficients } & \multicolumn{2}{c}{$\begin{array}{c}\text { Standardized } \\
\text { Coefficients }\end{array}$} & T & Sig. \\
& $\mathrm{B}$ & Std. Error & Beta & & \\
\hline \multirow{2}{*}{1} & (Constant) & 46.571 & 12.898 & & 3.611 & .000 \\
1 & Profitabilitas & -19.934 & 4.735 & -.353 & -4.210 & .000 \\
& Ukuran & 1.872 & .537 & .332 & 3.488 & .001 \\
& Perusahaan & & & & & \\
& Ukuran KAP & -1.464 & 4.698 & -.030 & -.312 & .756 \\
\hline
\end{tabular}

Sumber : Data diolah SPSS, 2021

Berdasarkan hasil pengujian parsial (uji t) maka dapat disimpulkan sebagai berikut:

a) Hasil dari uji parsial menunjukkan bahwa nilai t hitung sebesar 4,210 bertanda negatif dan nilai signifikansi 0,00 kecil dari 0,05 . Nilai t hitung dari variabel profitabilitas negatif $-4,210$ menunjukkan arah dari variabel profitabilitas sehingga dapat digambarkan bahwa variabel profitabilitas berpengaruh negatif dan signifikan terhadap audit delay.

b) Hasil dari uji parsial menunjukkan bahwa nilai t hitung 3,488 bertanda positif dan nilai signifikansi 0,001 kecil dari 0,05 . Nilai t hitung dari variabel ukuran perusahaan positif 3,488 menunjukkan arah dari variabel ukuran perusahaan sehingga dapat digambarkan bahwa variabel ukuran perusahaan berpengaruh positif dan signifikan terhadap audit delay.

c) Hasil dari uji parsial menunjukkan bahwa nilai t hitung 0,312 bertanda negatif dan nilai signifikansi 0,756 besar dari 0,05. Nilai t hitung dari variabel Ukuran KAP negatif -0,312 menunjukkan arah dari variabel ukuran KAP sehingga dapat digambarkan bahwa variabel ukuran perusahaan tidak berpengaruh terhadap audit delay.

\section{Uji F (Simultan)}

Uji $\mathrm{F}$ bertujuan untuk mengetahui apakah seluruh variabel independen yang dimasukkan dalam model secara bersama-sama (simultan) memiliki pengaruh yang bermakna terhadap variabel dependen.

\section{Tabel 9}

\begin{tabular}{llccccc}
\multicolumn{7}{c}{ Tabel 9 } \\
Uji F & & \\
\hline & Model & Sum of Squares & Df & Mean Square & F & Sig. \\
\hline 1 & Regression & 17505.903 & 3 & 5835.301 & 13.301 & $.000^{\mathrm{b}}$ \\
& Residual & 49133.925 & 112 & 438.696 & & \\
& Total & 66639.828 & 115 & & &
\end{tabular}

a. Dependent Variable: Audit Delay

b. Predictors: (Constant), Ukuran KAP, Profitabilitas, Ukuran Perusahaan

Sumber : Data diolah SPSS, 2021

Berdasarkan hasil uji F yang ditunjukan pada tabel 9 diatas diketahui bahwa hasil analisis regresi secara simultan diperoleh nilai F-statistik sebesar 13,301 dengan nilai signifikansi sebesar $0,000<0,05$ atau dapat dikatakan $\mathrm{H} 0$ ditolak dan $\mathrm{Ha}$ diterima, membuktikan bahwa semua variabel independen berpengaruh terhadap variabel dependen atau model regresi dalam penelitian ini tergolong baik. Sehingga dapat diperoleh kesimpulan bahwa variabel profitabilitas, ukuran perusahaan dan ukuran kantor akuntan publik berpengaruh signifikan terhadap audit delay secara simultan. 


\section{Analisis Koefisien Determinan}

Uji koefisien determinan bertujuan untuk menunjukkan seberapa dekat garis regresi cocok dengan data penelitian atau seberapa besar kemampuan variabel independen yang digunakan dalam persamaan regresi dalam menjelaskan varians variabel independen.

Tabel 10

Koefisien Determinan

\begin{tabular}{lcccc}
\hline \multicolumn{1}{c}{ Model } & $\mathrm{R}$ & $\mathrm{R}$ Square & Adjusted R Square & $\begin{array}{c}\text { Std. Error of the } \\
\text { Estimate }\end{array}$ \\
\hline 1 & $.513^{\mathrm{a}}$ & .263 & .243 & 20.945 \\
a. Predictors: (Constant), Ukuran KAP, Profitabilitas, Ukuran Perusahaan \\
b. Dependent Variable: Audit Delay
\end{tabular}

Pada Tabel 10 di atas dapat dilihat bahwa nilai dari Adjusted $\left(R^{2}\right)$ adalah sebesar 0,243 . Artinya bahwa varians variabel profitabilitas, ukuran perusahaan dan ukuran KAP mampu menjelaskan audit delay sebesar $24,3 \%$ sedangkan sisanya sebesar $75,7 \%$ dijelaskan oleh faktor-faktor lain yang tidak terdapat pada penelitian ini.

\section{Pembahasan Hasil Penelitian \\ Pengaruh Profitabilitas terhadap Audit Delay}

Dari hasil perhitungan diperoleh nilai t hitung negatif $-4,210$ menunjukkan arah dari variabel profitabilitas dan nilai signifikansi sebesar 0,000 lebih kecil dari $0,05(0,000<0,05)$. Hasil penelitian menggambarkan bahwa secara parsial variabel profitabilitas berpengaruh negatif dan signifikan terhadap audit delay. Dengan demikian hipotesis pertama yang menyatakan bahwa profitabilitas berpengaruh negatif terhadap audit delay diterima.

Variabel profitabilitas mempunyai hubungan berlawanan arah atau negatif terhadap audit delay. Menggambarkan bahwa perusahaan sektor pertambangan yang menjadi sampel dalam penelitian ini yaitu periode tahun 2017 sampai dengan tahun 2020 yang memiliki profitabilitas tinggi akan tepat waktu dalam mempublikasilan laporan keuangan auditannya sehingga dapat mengurangi lamanya audit delay. Karena perusahaan yang memiliki profitabilitas tinggi diartikan sebagai perusahaan pertambangan yang mampu menghasilkan keuntungan, sehingga memberikan goodnews bagi perusahaan dan cenderung melaporkan laporan keuangan auditannya tepat waktu. Jadi, dalam penelitian ini dapat disimpulkan bahwa perusahaan yang memiliki profitabilitas besar cenderung menyampaikan laporan keuangan tepat waktu, sehingga proses penyelesaian laporan audit menjadi lebih cepat dan audit delay relatif lebih singkat. Semakin besar profitabilitas suatu perusahaan yang diproksikan dengan ROE pada perusahaan sektor pertambangan maka semakin pendek audit delay yang dihasilkan.

Hasil penelitian ini sejalan dengan penelitian yang dilakukan oleh Putra \& Wiratmaja (2019) yang menyatakan bahwa profitabilitas memiliki pengaruh negarif terhadap audit delay yang artinya semakin tinggi profitabilitas suatu emiten maka semakin pendek audit delay. Hasil penelitian ini juga sejalan dengan penelitian Prabasari \& Merkusiwati (2017), Rusmin \& Evans (2017) dan Alfiani \& Nurmala (2020) yang menyatakan bahwa profitabilitas berpengaruh terhadap audit delay. Hasil penelitian ini bertolak belakang dengan penelitian yang dilakukan oleh Effendi (2018) dan Lestari \& Nuryatno (2018) yang menyatakan bahwa profitabilitas tidak berpengaruh signifikan terhadap audit delay.

\section{Pengaruh Ukuran Perusahaan terhadap Audit Delay}

Dari hasil perhitungan diperoleh nilai t hitung positif 3,488 menunjukkan arah dari variabel profitabilitas dan nilai signifikansi sebesar 0,001 lebih kecil dari $0,05(0,001<0,05)$. 
Hasil penelitian menunjukkan bahwa secara parsial variabel ukuran perusahaan berpengaruh positif dan signifikan terhadap audit delay. Dengan demikian hipotesis kedua yang menyatakan ukuran perusahaan berpengaruh positif terhadap audit delay diterima.

Total aset yang dimiliki oleh perusahaan ternyata mempunyai pengaruh positif dan signifikan terhadap audit delay, hal ini dikarenakan semakin besar perusahaan maka semakin panjang audit delay. Perusahaan sektor pertambangan yang memiliki total aset yang besar, maka akan menghasilkan laporan audit lebih lama dibandingkan dengan perusahaan yang mempunyai total aset yang lebih kecil, karena jumlah sampel yang diambil semakin besar dan semakin banyak prosedur audit yang ditempuh. Perusahaan dengan total aset yang tinggi tidak memberikan jaminan bahwa audit delay akan semakin singkat. Jadi, dalam penelitian ini dapat disimpulkan bahwa perusahaan pertambangan yang terdaftar di BEI tahun 2017-2020 yang memiliki total aset lebih besar akan menghasilkan audit delay yang lebih panjang. Karena perusahaan besar cenderung memiliki kompleksitas operasional yang tinggi, sehingga diperlukan proses audit yang relatif lama dan menyebabkan audit delay lebih lama.

Hasil penelitian ini sejalan dengan penelitian yang dilakukan oleh Clarisa \& Pangerapan (2019) yang menyatakan bahwa ukuran perusahaan berpengaruh positif terhadap audit delay yang artinya semakin besar ukuran perusahaan maka audit delay akan semakin panjang karena perusahaan yang memiliki ukuran lebih besar memiliki aktivitas, volume kegiatan dan kuantitas transaksi yang besar pula sehingga menyebabkan terjadinya audit delay. Hasil penelitian ini juga sejalan dengan penelitian yang dilakukan oleh Hassan (2016), Kaaroud et al., (2020) dan Al-Qublani dkk (2020) yang menyatakan bahwa ukuran perusahaan secara signifikan berpengaruh terhadap laporan audit yang lebih lama atau audit delay yang semakin lama. Hasil penelitian ini bertolak belakang dengan penelitian yang dilakukan oleh Lestari \& Saitri (2017), Prastiwi dkk (2018) dan Lai dkk (2020) yang menyatakan bahwa ukuran perusahaan tidak berpengaruh terhadap audit delay.

\section{Pengaruh Ukuran KAP terhadap Audit Delay}

Dari hasil perhitungan diperoleh nilai t hitung negatif $-0,312$ menunjukkan arah dari variabel ukuran KAP dan nilai signifikansi 0,756 lebih besar dari $0,05(0,756>0,05)$. Hasil penelitian menunjukkan bahwa secara parsial variabel ukuran KAP tidak berpengaruh terhadap audit delay. Dengan demikian hipotesis ketiga yang menyatakan ukuran KAP berpengaruh negatif terhadap audit delay ditolak. Hal ini karena seorang auditor yang berasal dari KAP big four ataupun KAP non big four akan tetap melaksanakan standar auditing yang ditetapkan oleh Ikatan Akuntan Indonesia (IAI), sehingga tidak berpengaruh terhadap rentang waktu penyampaian laporan audit atas laporan keuangan.

Perusahaan yang diaudit oleh KAP big four maupun perusahaan yang diaudit oleh KAP non big four tidak akan mempengaruhi waktu penyampaian laporan keuangann, karena perusahaan yang diaudit KAP big four maupun KAP non big four tentunya akan berusaha memberikan kualitas audit yang baik dan menunjukkan profesionalitas yang tinggi kepada perusahaan yang diauditnya.

Hal ini juga tentunya berguna untuk kelangsungan dan untuk mempertahankan eksistensi kantor akuntan publik yang bersangkutan. Jadi panjang pendeknya audit delay tidak ditentukkan oleh ukuran KAP yang digunakan oleh perusahaan pertambangan yang terdaftar di BEI tahun 2017-2020. Hasil penelitian tidak sesuai dengan teori yang menyatakan bahwa perusahaan yang diaudit oleh KAP big four cenderung memiliki audit delay yang lebih singkat. Hasil penelitian menunjukkan bahwa perusahaan yang diaudit oleh KAP Big Four maupun KAP non big four tidak menjamin bahwa tidak akan terjadinya audit delay. Jadi ukuran kantor akuntan publik tidak mempengaruhi lamanya waktu penyelesaian laporan keuangan. Sehingga dapat disimpulkan bahwa perusahaan pertambangan yang diaudit oleh 
KAP big four maupun KAP non big four tidak memiliki pengaruh terhadap panjang pendeknya audit delay.

Hasil penelitian ini sejalan dengan penelitian yang dilakukan dengan Effendi (2018) yang menyatakaan bahwa ukuran KAP tidak berpengaruh terhadap audit delay. Hasil penelitian ini mendukung hasil penelitian terdahulu yang dilakukan oleh Lestari \& Nuryatno (2018) yang menyatakan bahwa audit reputasi tidak berpengaruh terhadap audit delay. Hasil penelitian ini bertolak belakang dengan hasil penelitian yang dilakukan oleh Khoufi \& Khoufi (2018) yang menyatakan bahwa adanya hubungan negatif dan signifikan antara ukuran KAP terhadap audit delay. Hasil penelitian ini juga tidak sejalan dengan penelitian yang dilakukan oleh Alfiani \& Nurmala (2020) yang menyatakan bahwa variabel reputasi kantor akuntan publik (KAP) berpengaruh positif dan signifikan terhadap audit delay.

\section{KESIMPULAN DAN SARAN \\ Kesimpulan}

Dari hasil pengujian yang dilakukan maka peneliti dapat menarik kesimpulan-kesimpulan sebagai berikut:

a) Hasil pengujian secara parsial menunjukkan bahwa variabel profitabilitas berpengaruh negatif terhadap audit delay pada perusahaan sektor pertambangan yang terdaftar di Bursa Efek Indonesia (BEI) periode 2017-2020.

b) Hasil pengujian secara parsial menunjukkan bahwa variabel ukuran perusahaan berpengaruh positif terhadap audit delay pada perusahaan sektor pertambangan yang terdaftar di Bursa Efek Indonesia (BEI) periode 2017-2020.

c) Hasil pengujian secara parsial menunjukkan bahwa variabel ukuran KAP tidak berpengaruh terhadap audit delay pada perusahaan sektor pertambangan yang terdaftar di Bursa Efek Indonesia (BEI) periode 2017-2020.

d) Variabel profitabilitas, ukuran perusahaan dan ukuran KAP secara simultan berpengaruh signifikan terhadap audit delay pada perusahaan sektor pertambangan yang terdaftar di BEI periode 2017-2020.

\section{Saran}

Untuk auditor diharapkan dapat lebih cermat dan teliti dalam proses audit sehingga audit delay dapat ditekan seminimal mungkin dan laporan keuangan dapat dipublikasikan secara tepat waktu. Untuk peneliti selanjutnya diharapkan dapat menambah variabel-variabel lain yang sekiranya berpengaruh terhadap audit delay baik yang berasal dari faktor ekternal seperti kualitas auditor dan opini audit, maupun dari faktor internal seperti kompleksitas laporan keuangan dan umur perusahaan. Peneliti selanjutnya juga dapat menggunakan variabel kontrol, sehingga kedepannya dapat diperoleh hasil yang maksimal. Variabel yang tidak berpengaruh dapat dikaji ulang oleh peneliti selanjutnya agar dapat memperoleh konsistensi hasil penelitian.

\section{DAFTAR PUSTAKA}

Al-Qublani, A. A. M., Kamardin, H., \& Shafie, R. (2020). Audit committee chair attributes and audit report lag in an emerging market. International Journal of Financial Research, 11(4), 475-492. https://doi.org/10.5430/ijfr.v11n4p475

Alfiani, \& Nurmala. (2020). Pengaruh Ukuran Perusahaan, Profitabilitas, Solvabilitas dan Reputasi Kantor Akuntan Publik terhadap Audit Delay. Journal of Technopreneurship on Economics and Business Review, 1(2), 79-99.

Amani, F. A., \& Waluyo, I. (2016). PENGARUH UKURAN PERUSAHAAN, PROFITABILITAS, OPINI AUDIT, DAN UMUR PERUSAHAAN TERHADAP AUDIT DELAY (Studi Empiris pada Perusahaan Property dan Real Estate yang 
Terdaftar di Bursa Efek Indonesia pada Tahun 2012-2014). Nominal, Barometer Riset Akuntansi Dan Manajemen, 5(1). https://doi.org/10.21831/nominal.v5i1.11482

Annisa, D. (2018). Pengaruh Ukuran Perusahaan, Jenis Opini Auditor, Ukuran Kap Dan Audit Tenure Terhadap Audit Delay. Jurnal Akuntansi Berkelanjutan Indonesia, 1(1), 108. https://doi.org/10.32493/jabi.v1i1.y2018.p108-121

Ariani, K. R., \& Bawono, A. D. B. (2018). PENGARUH UKURAN DAN UMUR PERUSAHAAN TERHADAP AUDIT REPORT LAG DENGAN PROFITABILITAS DAN SOLVABILITAS SEBAGAI VARIABEL MODERATING. Riset Akuntansi Dan Keuangan Indonesia, 3(2), 118-126.

Ashton, R. H., Willingham, J. J., \& Elliott, R. K. (1987). An Empirical Analysis of Audit Delay. Journal of Accounting Research, 25(2), 275. https://doi.org/10.2307/2491018

Clarisa, S., \& Pangerapan, S. (2019). Pengaruh Ukuran Perusahaan, Solvabilitas, Profitabilitas, Dan Ukuran Kap Terhadap Audit Delay Pada Perusahaan Sektor Pertambangan Yang Terdaftar Di Bursa Efek Indonesia. Jurnal EMBA: Jurnal Riset Ekonomi, Manajemen, Bisnis Dan Akuntansi, 7(3), 3069-3078. https://doi.org/10.35794/emba.v7i3.24060

Devina, N., \& Fidiana. (2019). Pengaruh Ukuran Perusahaan, Profitabilitas,Ukuran KAP, Audit Tenure, dan Solvabilitas Terhadap Audit Delay. Jurnal Ilmu Dan Riset Akuntansi, $8(2), 1-17$.

Effendi, B. (2018). Pengaruh Ukuran Perusahaan dan Ukuran KAP terhadap Audit Delay . E-Jurnal Akuntansi.

Eksandy, A. (2017). PENGARUH UKURAN PERUSHAAN, SOLVABILITAS, PROFITABILITAS DAN KOMITE AUDIT TERHADAP AUDIT DELAY (Pada Perusahaan Properti dan Real Estate yang Terdaftar di Bursa Efek Indonesia Pada Tahun 2012-2015, 1(2).

Ferri, M. G., \& Jones, W. H. (1979). Determinants of Financial Structure: a New Methodological Approach, 34(3), 631-644.

Harjanto, K. (2017). Pengaruh Ukuran Perusahaan, Profitabilitas, Solvabilitas, dan Ukuran Kantor Akuntan Publik terhadap Audit Delay. Jurnal ULTIMA Accounting, 9(2), 33-49. https://doi.org/10.31937/akuntansi.v9i2.728

Hassan, Y. M. (2016). Determinants of audit report lag: evidence from Palestine. Journal of Accounting in Emerging Economies, 6(1), 13-32. https://doi.org/10.1108/jaee-05-20130024

https://market.bisnis.com/read/20200709/7/1263701/bursa-efek-indonesia-denda-puluhanjuta-42-perusahaan-ini-penyebabnya. (Diaskes tanggal 29 Maret 2020)

Ikatan Akuntansi Indonesia.PSAK No. 1 Tentang Laporan Keuangan-edisi revisi 2015. Penerbit Dewan StandarAkuntansi Keuangan: PT. Raja Grafindo

Jayanti, F. D. (2018). Pengaruh Ukuran Perusahaan, Kualitas Audit Dan Profitabilitas Terhadap Kecepatan Waktu Dalam Penyampaian Laporan Keuangan. Akuisisi: Jurnal Akuntansi, 14(1), 26-33. https://doi.org/10.24127/akuisisi.v14i1.238

Jensen, M. C., \& Meckling, W. H. (1976). Theory of the firm: Managerial Behavior Agency Costs And Ownership Structure. Financial Economics, 305-360. https://doi.org/10.1177/0018726718812602

Kaaroud, M. A., Mohd Ariffin, N., \& Ahmad, M. (2020). The extent of audit report lag and governance mechanisms: Evidence from Islamic banking institutions in Malaysia. Journal of Islamic Accounting and Business Research, 11(1), 70-89. https://doi.org/10.1108/JIABR-05-2017-0069

Karang, N. M. D. U., Yadnyana, I. K., \& Ramantha, I. W. (2015). Pengaruh Faktor Internal dan Eksternal Pada Audit Delay. E-Jurnal Ekonomi Dan Bisnis Universitas Udayana, 4(07), 473-488, ISSN: 2337-3067.

Khoufi, N., \& Khoufi, W. (2018). An empirical examination of the determinants of audit 
report delay in France. Managerial Auditing Journal, 33(8-9), 700-714. https://doi.org/10.1108/MAJ-02-2017-1518

Keputusan Ketua Badan Pengawas Pasar Modal Dan Lembaga Keuangan Nomor: Kep431/B1/2012 Tentang Penyampaian Laporan Tahunan Emiten Atau Perusahaan Publik

Lai, T. T. T., Tran, M. D., Hoang, V. T., \& Nguyen, T. H. L. (2020). Determinants influencing audit delay: The case of Vietnam. Accounting, 6(5), 851-858. https://doi.org/10.5267/j.ac.2020.5.009

Lestari, K. A. N. M. L., \& Saitri, P. W. (2017). Analisis Pengaruh Ukuran Perusahaan, Profitabilitas, Solvabilitas, Kualitas Auditor dan Audit Tenure Terhadap Audit Delay pada Perusahaan Manufaktur di Bursa Efek Indonesia Periode 2012-2015. Jurnal Ilmiah Manajemen \& Bisnis, 23(1), 1-11.

Lestari, S. Y., \& Nuryatno, M. (2018). Factors Affecting the Audit Delay and Its Impact on Abnormal Return in Indonesia Stock Exchange. International Journal of Economics and Finance, 10(2), 48. https://doi.org/10.5539/ijef.v10n2p48

Liwe, A. G. dan H. M. dan L. M. M. (2018). Analisis faktor-faktor yang Mempengaruhi Audit Delay (Studi Empiris pada perusahaan Properti yang ada di BEI). Jurnal Riset Akuntansi Going Concern 13(2), 2018, 99-108, 13(A), 99-108.

Murti, N. M. D. A., \& Widhiyani, N. L. S. (2016). PENGARUH UKURAN PERUSAHAAN DAN PROFITABILITAS PADA AUDIT DELAY DENGAN REPUTASI KAP SEBAGAI VARIABEL PEMODERASI. E-Jurnal Akuntansi Universitas Udayana, 16(1), 275-305. https://doi.org/10.1007/978-3-319-45246-3_44

Oktavia, H. D., \& Suryaningrum, D. H. (2018). Pengaruh Profitabilitas, Opini Auditor, dan Ukuran Perusahaan Terhadap Ketepatan Waktu Penyampaian Laporan Keuangan di Bursa Efek Indonesia Periode Tahun 2012-2014. Jurnal Keuangan Dan Bisnis, 16(1), 100. https://doi.org/10.32524/jkb.v16i1.368

Prabasari, I. G., \& Merkusiwati, N. K. (2017). Pengaruh Profitabilitas, Ukuran Perusahaan, Dan Komite Audit Pada Audit Delay Yang Dimoderasi Oleh Reputasi Kap. E-Jurnal Akuntansi, 20(2), 1704-1733. https://doi.org/10.24843/EJA.2017.v20.i02.p30

Prastiwi, P. I., Astuti, D., \& Harimurti, F. (2018). PENGARUH UKURAN PERUSAHAAN, LEVERAGES, SISTEM PENGENDALIAN INTERNAL, DAN REPUTASI AUDITOR TERHADAP AUDIT DELAY DENGAN AUDIT TENURE SEBAGAI VARIABEL MODERASI, 14(1), 89-99.

Putra, A. C., \& Wiratmaja, I. D. N. (2019). Pengaruh Profitabilitas Dan Kompleksitas Operasi Pada Audit Delay Dengan Ukuran Perusahaan Sebagai Variabel Moderasi. E-Jurnal Akuntansi, 27, 2351. https://doi.org/10.24843/eja.2019.v27.i03.p26

Putri, D. A. (2020). Analisis Faktor - Faktor yang Mempengaruhi Ketepatan Waktu Penyampaian Laporan Keuangan Perusahaan Industri Barang Konsumsi di Bursa Efek Indonesia. Jurnal Ekonomi Islam, 5(2), 333-353.

Pusat Pembinan Profesi Keuangan Kementerian Keuangan Republik Indonesia. (2015). "Profil Akuntan Publik dan Kantor Akuntan Publik 2014", Jakarta.

Rusmin, R., \& Evans, J. (2017). Audit quality and audit report lag: Case of Indonesian listed companies. Asian Review of Accounting, 25(2).

Sari, D. P., \& Mulyani, E. (2019). Faktor-Faktor yang mempengaruhi Audit Delay (Studi Empiris Pada Perusahaan Pertambangan Yang Terdaftar di Bursa Efek Indonesia Tahun 2014-2017). Universitas Negeri Padang, 1(2), 646-665. Retrieved from http://jea.ppj.unp.ac.id/index.php/jea/issue/view/6

Shaena, U., Yusuf, M., \& Hidayah, R. (2020). Faktor-Faktor Yang Dapat Mempengaruhi Audit Delay. Jurnal Neraca, 16(1), 71-89. Retrieved from www.idx.co.id

Sugiyono., 2016. Metode Penelitian Kuantitatif, Kualitatif, dan $R$ \& D. CV. Alfabeta: Bandung. 
Widiastuti, I. D., \& Kartika, A. (2018). Ukuran Perusahaan, Profitabilitas, Umur Perusahaan, Solvabilitas dan Ukuran Kap Terhadap Audit Report Lag. Dinamika Akuntansi, Keuangan Dan Perbankan, 7(1), 20-34. Retrieved from https://www.unisbank.ac.id/ojs/index.php/fe9/article/view/7443

Yunita, Y., \& Syofyan, E. (2017). Analisis Faktor-Faktor Yang Mempengaruhi Audit Delay: Studi Empiris Pada Perusahaan Manufaktur Yang Terdaftar Di BEI Tahun 2011-2015. Jurnal Wahana Riset Akuntansi, 5. 